attracted to his laboratory many of the younger Survey men of his time. These he trained in his methods, and inspired and encouraged not a few of them to original research and subsequent distinction within and without the Survey. The output of his scientific work during this period was truly remarkable, comprising as it did petrographical contributions to no fewer than thirty official memoirs, the classic "Report on the Eruptions of the Soufrière in St. Vincent, in 1902, and on a visit to Montagne Pelée, in Martinique" (with Tempest Anderson), "The Geology of the Lizard and Meneage" (with J. B. Hill), and numerous contributions to scientific journals some of which were written in collaboration with his colleagues. In addition he contributed eighty-three petrological articles to the "Encyclopædia Britannica" (11th edition, 1910), and it is noteworthy testimony to the soundness and permanence of his work that thirty-three of these contributions appear in the 14th edition (1929).

In 1911 Flett succeeded the late Dr. John Horne as assistant to the director in Scotland, and thereafter became more and more immersed in Survey business and administration. He took an active and personal interest in every branch of Survey work, made extended visits to the field and familiarized himself with the numerous problems which constantly arise in the production and publication of geological maps and memoirs. The outbreak of war in 1914 caused serious depletion of the Survey staff, many of whom volunteered and were accepted for active service, and at the same time imposed on the directorate new tasks and responsibilities in the search for, and assessment of, available resources of raw materials in short supply, and in meeting insistent demands for geological information relating to the sites of camps, training centres, aerodromes and factories at home and to military operations overseas. Flett tackled these new tasks with characteristic energy. $\mathrm{He}$ not only organised and directed the Scottish section of the work but also undertook a considerable amount of field investigation and made substantial personal contributions to the numerous reports prepared for the information of service and supply departments. His reputation as geologist, petrographer and administrator was now firmly established and fully justified his selection in 1920 to succeed the late Sir Aubrey Strahan as director of the Geological Survey and Museum, a post he filled with conspicuous distinction and success for fifteen years.

The record of achievement of the Geological Survey and Museum during this period is an impressive one. The arrears of work, an inevitable legacy of four years of war, were rapidly overtaken, the staff was enlarged and reorganised, district offices were established in the coalfields, and the work of bringing up to date and publishing the geological information relating to these vitally important areas was prosecuted with an unprecedented vigour and resulted in a steady outflow of maps, memoirs and special reports. Nor were the purely scientific aspects of geology neglected. The surveys of the great volcanic complexes of Mull and Ardnamurchan were completed and the results embodied in maps and memoirs which stand unrivalled as classic records of perhaps the most complicated structures ever mapped by the Geological Survey. Similarly, the extensive complexes of schist and granite of central and northern Sutherland were mapped and described, and the field survey of the Orkney and Shetland Islands was completed.
Throughout this period of strenuous activity Flett steadily pursued the scheme, proposed in 1912 by the Bell Committee, for the transference of the Geological Survey and Museum from the inadequate and congested accommodation in Jermyn Street to a new and more spacious building in South Kensington. The culmination of his efforts came in July 1935, when the King (then Duke of York) formally opened the new Geological \Museum and Survey offices in Exhibition Road, and the institution, served so long, so devotedly and to such purpose, celebrated its centenary. Two months later Flett retired from the public service. In his retirement he continued with characteristic energy his geological pursuits and his deep interest in all matters connected with the Survey and Museum. He saw through the press his memorial volume, "The First Hundred Years of the Geological Survey", written during the last period of his directorship, revised the Lizard map and prepared a second edition of the memoir now being printed, and took the greatest pleasure in stimulating his colleagues and "his young men" to fresh endeavour for his beloved science. Active to the end, he died with startling suddenness in the garden of his cottage at Ashdon, Essex, on January 26.

Many honours came to Flett in the course of his long and brilliant career. He was a fellow of the Royal Societies of London and Edinburgh, Bigsby and Wollaston Medallist of the Geological Society, LL.D. of his own University, created K.B.E. in 1925, president of Section C of the British Association in 1921, president of the Mineralogical Society, and member and correspondent of numerous societies in the Dominions and foreign countries where he had travelled extensively. But what he valued most of all was the satisfaction of endeavour and achievement, and his name is permanently woven into the fabric of Survey history and tradition as a great geologist and a great director.

W. F. P. McLintock

\section{Prof. George L. Funke}

Prof. George L. Funke, professor of botany in the University of Ghent, died on December 15 at the age of fifty, after an operation. He was Dutch, born at The Hague on May 29, 1896, and was educated at Amsterdam and Utrecht. $\mathrm{He}$ graduated at the University of Utrecht in 1922 with a doctorate in botany and zoology. After some years as lecturer in Holland, he went in 1934 to Belgium as a lecturer at the University of Ghent, where he became an ordinary professor in 1937; during the War and the German occupation of Belgium, he was forced to go back to Holland, being deprived by the Germans of his post, which he resumed, however, in 1945.

Prof. Funke, who was unmarried, displayed an uncommon energy and an almost youthful enthusiasm in every kind of activity he took up; as director of the Botanical Laboratories at the University of Ghent, he paid much attention to the practical side of his work, and defended, at times against powerful odds, the teaching of biology in schools. His purely scientific work was of importance, particularly with regard to the question of the influence of the light on plant development. Inspired by the investigations of Dr. Fröschel, he developed a new branch of botanical science which may be called 'experimental plant sociology'; a book on this subject, it is expected, will shortly be published in the United States.

P. VAN OYE 